\title{
Організаційно-економічне забезпечення розвитку територіальної структури регіонального господарювання
}

\begin{abstract}
Виявлено проблеми формування та розвитку територіальної структури регіонального господарювання. Узагальнено існуючі теоретичні дослідження щүодо особливостей формування та розвитку територіальної структури регіонального господарювання. Обтрунтовано доцільність формування організаційно-економічного забезпечення розвитку територіальної структури регіонального господарювання. Відзначено, щцо для вирішення завдань координації та взаємодії всіх зацікавлених сторін у формуванні та розвитку територіальних структур господарства, для запобігання "розпилення сил" $і$ дублювання функцій доцільно охарактеризувати складові ї̈ організаційно-економічного забезпечення.

Розроблено концепцію організаційно-економічного забезпечення розвитку територіальної структури регіонального господарювання.
\end{abstract}

Ключові слова: територіальна структура, регіональне господарювання, розвиток, формування, організаційно-економічне забезпечення.

Вступ

Сучасні умови впровадження територіальної реформи накладають певний відбиток на структуру регіонального господарювання. Для забезпечення ефективного розвитку регіону, підвищення рівня регіональної економіки, необхідне вдосконалення організаційно-економічного забезпечення територіальної структури регіонального господарювання, що, в свою чергу, визначається специфікою i складністю управління ними. Організаційноекономічне забезпечення територіальної структури регіонального господарювання передбачає формування і розвиток системи відносин між широким колом учасників, які ініціюють, впроваджують та підтримують розвиток на регіональному рівні. Вони багато в чому створюють передумови якісної адаптації регіону до змін. Багато досліджень підтверджують, що сталий розвиток регіонального господарювання в довгостроковій перспективі залежить не лише від ресурсних можливостей, а й від організаційної складової.

Організаційно-економічні основи регіональної діяльності передбачають вирішення наступних завдань розвитку: забезпечення розширеного відтворення регіональних ресурсів; розвиток регіональної інфраструктури; створення сприятливих умов для економічної діяльності; кадрове забезпечення; розвиток вузівського і наукового секторів регіону, які служать найважливішою інтелектуальної передумовою підвищення регіонального потенціалу, і ін. [1]
Об'єктивна необхідність розвитку територіальних структур зумовлена історично сформованими традиціями, диференціацією їх соціально-економічного стану, можливістю підвищення рівня зайнятості населення в регіонах, забезпечення населення високоякісною продукцією, розвитком альтернативних видів діяльності і підвищенням на цій основі прибутковості регіональної економіки [2].

Науково обгрунтована розробка елементів організаційно-економічного забезпечення розвитку територіальних структур та визначення його основних параметрів багато в чому залежать від правильності постановки та структурування цілей і завдань, раціонального використання ресурсів для їх рішення і послідовності планованих заходів. Розробка організаційноекономічного забезпечення розвитку територіальних структур вимагає всебічного аналізу існуючих тенденцій i проблем в структурі економіки, в розвитку виробничої, соціальної, ринкової інфраструктури, соціальній та екологічній сферах, у фінансовій діяльності організацій, функціонуванні фінансових і кредитних інститутів [3].

Таким чином створення ефективної територіальної структури регіонального господарювання стає неможливим без належного організаційно-економічного забезпечення. У зв'язку 3 цим виникає необхідність вивчення основних складових організаційного забезпечення територіальної структури регіонального господарювання. 


\section{Аналіз останніх досліджень і публікацій \\ Досліджуванню організаційно-} економічного забезпечення формування територіальних структур регіонального господарювання присвячені роботи, як вітчизняних, так зарубіжних авторів, зокрема таких як В. Герасенко, С. Гребенкіна, C. Жубаркін, Д. Кузнєцов, Р. Лепа, I. Маєргойз, О. Руссіян, А. Токарєв, С. Школинський та ін. [1-8]. Слід зауважити, що різні точки зору, представлені в цих роботах, не вирішують проблему в силу того, ще існує єдиної думки щодо складових частин організаційно-економічного забезпечення розвитку територіальної структури регіонального господарювання. Таким чином дана проблема вимагає більш системного вивчення.

\section{Мета статті}

Дослідження основних складових організаційно-економічного забезпечення розвитку територіальної структури регіонального господарювання.

\section{Методи дослідження}

Для досягнення поставленої мети було використано такі методи наукового дослідження: узагальнення; аналізу і синтезу; абстрактно-логічний.

\section{Виклад основного матеріалу.}

Процес розвитку територіальної структури регіонального господарювання можна охарактеризувати як такий, що постійно змінюється. Багатоманітність i масштаби використання в господарстві території на кожному історичному етапі залежать від конкретних цільових установок розвитку суспільства та умов протікання процесу просторової структуризації господарства (територіального розподілу виробничого потенціалу, інфраструктури, населення і природних ресурсів, науковотехнічного прогресу і ін.). Значний вплив на розвиток чинить ймовірність прояву багатьох компонентів територіальної структури. Тому для глибокого пізнання закономірностей формування територіальної структури регіонального господарювання представляється доцільним розглядати іiі в розмаїтті головних елементів, стійких зв'язків та інших відносин.

Складність процесу територіальної структуризації господарювання регіонального нтегральністю, взаємозалежностей між соціальноекономічними i природними об'єктами. Основні труднощі пов'язані, головним чином, 3 тим, що має місце змінювання економічної значущості певних територіальних об'єктів, яке відбуваються нерівномірно.

На основі проведеного аналізу теоретичних досліджень розвитку територіальної структури регіонального господарювання виявлено, що:

1. Категорія територіальної структури регіонального господарювання затвердилася в регіональній економічній науці еволюційним шляхом на основі розроблених раніше уявлень про територіальний поділ праці, економічні райони, територіальновиробничі комплекси, територіальні соціально-економічні системи та ін.

$$
\text { 2. Територіальну структуру }
$$

регіонального господарювання, що представляє собою сукупність взаємопов'язаних економічних об'єктів на конкретній території, необхідно розглядати як матеріальну основу територіальних соціально-економічних систем, які в свою чергу визначають соціально-економічне районування території.

3. Територіальну структуру регіонального господарювання необхідно розглядати як основний предмет вивчення регіональної економічної науки, в якому сфокусовані всі особливості та просторові параметри господарства території будьякого масштабу (країни, регіону).

4. Поліструктурність територіальних соціально-економічних систем виражається наявністю, за визначенням I.M. Маєргойза, триєдиної структури: лінійно-вузлової, територіально-галузевої та інтегральної. Остання $\epsilon$ континуальним утворенням різного ієрархічного рівня (райони, зони та ін.) [4].

5. Соціально-економічний розвиток регіонів супроводжується змінами в територіальній структурі регіонального господарювання, що виражається в зміні просторових параметрів господарських об'єктів і зв'язків між ними.

Отже, територіальна структура регіонального господарювання є своєрідною формою організації суспільства, яка включає взаємопов'язані елементи, може бути багаторівневою, наділена певними властивостями та призначена створювати 
сприятливе середовище для існуючих та майбутніх поколінь на основі принципів раціоналізації, системності, нормативності, відповідності та відповідальності.

Для вирішення завдань координації та взаємодії всіх зацікавлених сторін - органів місцевого самоврядування, представників бізнесу, громадськості - у формуванні та розвитку територіальних структур господарства, для запобігання «розпилення сил» i дублювання функцій доцільно охарактеризувати складові іiі організаційноекономічного забезпечення (табл. 1).

Таблиця 1

Характеристика складових організаційно-економічного забезпечення територіальної структури регіонального господарювання

\begin{tabular}{|c|c|c|c|c|}
\hline & \multicolumn{4}{|c|}{ Складові територіальної структури регіонального господарювання } \\
\hline & $\begin{array}{l}\text { Політико- } \\
\text { правова }\end{array}$ & Економічна & Соціальна & $\begin{array}{c}\text { Організаційно- } \\
\text { адміністративна }\end{array}$ \\
\hline $\begin{array}{l}\text { Мета формування } \\
\text { територіальної } \\
\text { структури }\end{array}$ & \multicolumn{4}{|c|}{$\begin{array}{l}\text { Створення умов для підвищення якості життя населення і зростання організаційно-економічної } \\
\text { i фінансової спроможності }\end{array}$} \\
\hline Суб’єкти & $\begin{array}{l}\text { Уряд, органи } \\
\text { місцевого } \\
\text { самоврядування }\end{array}$ & $\begin{array}{l}\text { Органи місцевого } \\
\text { самоврядування, бізнес- } \\
\text { структури }\end{array}$ & $\begin{array}{l}\text { Органи місцевого } \\
\text { самоврядування, } \\
\text { населення }\end{array}$ & $\begin{array}{l}\text { Органи місцевого } \\
\text { самоврядування }\end{array}$ \\
\hline $\begin{array}{l}\text { Цілі складових } \\
\text { територіальної } \\
\text { структури }\end{array}$ & $\begin{array}{c}\text { Формування } \\
\text { правових норм, } \\
\text { які сприятимуть } \\
\text { вирішенню } \\
\text { завдань } \\
\text { регіональної } \\
\text { політики }\end{array}$ & $\begin{array}{c}\text { Економічне зростання, } \\
\text { сталий розвиток } \\
\text { (економічна ефективність, } \\
\text { фінансова спроможність, } \\
\text { зростання ВРП і т. д.) }\end{array}$ & $\begin{array}{c}\text { Зростання якості } \\
\text { життя населення } \\
\text { (підвищення рівня } \\
\text { зайнятості, індексу } \\
\text { людського } \\
\text { потенціалу і ін.) }\end{array}$ & $\begin{array}{l}\text { Чітка координація } \\
\text { дій, раціональність } \\
\text { поведінки суб'єктів }\end{array}$ \\
\hline Методи & $\begin{array}{c}\text { Розробка і } \\
\text { прийняття } \\
\text { нормативно- } \\
\text { правових актів, } \\
\text { державних } \\
\text { програм; } \\
\text { контроль за } \\
\text { дотримання } \\
\text { законодавства }\end{array}$ & \multicolumn{2}{|c|}{$\begin{array}{l}\text { Стратегії, програми, проекти соціально- } \\
\text { економічного розвитку }\end{array}$} & $\begin{array}{c}\text { Стратегії, проекти, } \\
\text { програми, } \\
\text { обмежуючі заходи у } \\
\text { формування } \\
\text { інфраструктури, } \\
\text { методи підвищення } \\
\text { інвестиційного } \\
\text { іміджу }\end{array}$ \\
\hline Інструменти & $\begin{array}{c}\text { Закони, } \\
\text { постанови }\end{array}$ & $\begin{array}{c}\text { Державна участь в } \\
\text { проектах, гарантії, } \\
\text { кредитування, податкові } \\
\text { пільги, дотації, субвенції }\end{array}$ & $\begin{array}{c}\text { Організація нових } \\
\text { робочих місць, } \\
\text { підготовки і } \\
\text { перепідготовки } \\
\text { кадрів }\end{array}$ & $\begin{array}{l}\text { Реєстрація, } \\
\text { ліцензування, } \\
\text { форуми, наради }\end{array}$ \\
\hline
\end{tabular}

Процес розвитку територіальної структури регіонального господарювання представляється доцільним забезпечити концепцією організаційно-економічного забезпечення, до якої включити наступні складові:

- комплексний аналіз організаційноекономічних і фінансових передумов формування територіальної структури;

- формування $\mathrm{i}$ розвиток
територіальної структури регіонального господарювання шляхом організаційноекономічного і фінансового забезпечення; забезпечення регіонального стратегічного розвитку територіальної структури.

Запропонована організаційно-економічного концепція забезпечення розвитку територіальної структури, а також завдання, які вирішуються на різних рівнях, показані на рис. 1.

Одним 3 найважливіших елементів концепції організаційно-економічного забезпечення територіальної структури $€$ механізм оцінки факторів внутрішнього i зовнішнього впливу. Перелік оцінюваних характеристик факторів та їх кількісні показники визначаються методом експертних оцінок.

3 метою забезпечення оптимальності формування територіальної структури регіонального господарювання та відповідності ऑii довгостроковим цілям регіональної політики і інтересам населення пропонується методика контролю, яка заснована на процесі структурно-логічної 
фільтрації різноманітних факторів несприятливого впливу i забезпечує ефективне управління процесом формування i розвитку територіальної структури всіх етапах.

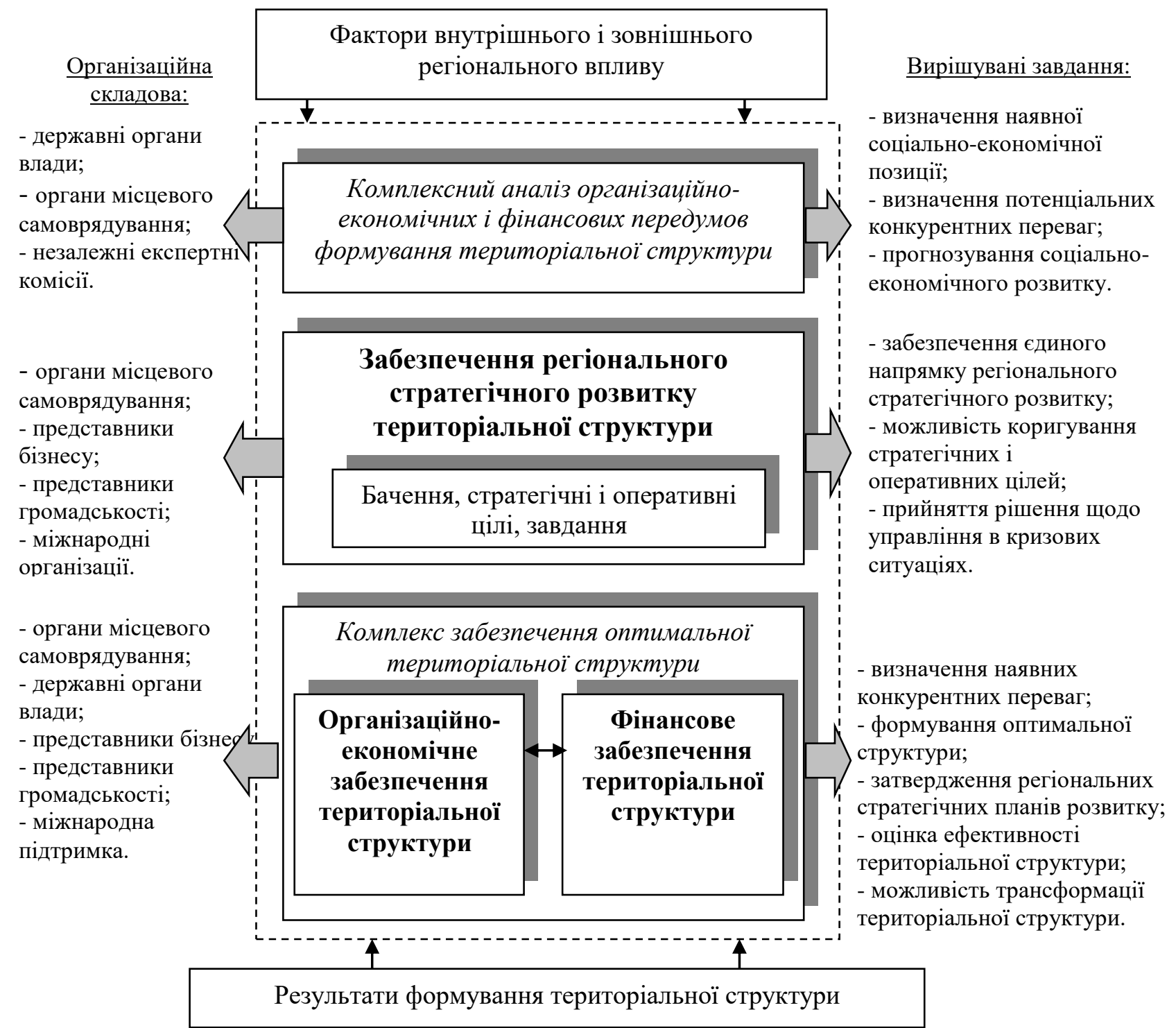

Рис. 1. Складові організаційно-економічного забезпечення територіальної структури регіонального господарювання

Відповідно до методики контролю формування територіальної структури господарства передбачається логічно послідовне проходження чотирьох структурно-логічних фільтрів, що забезпечують включення в процедуру формування всіх необхідних параметрів i встановлення iii відповідності всім критеріям, зокрема стратегії регіонального розвитку.

Фільтром цілей забезпечується співвідношення спрямованості стратегічних i оперативних цілей територіальної структури господарювання та стратегії регіонального розвитку. Територіальна структура повинна формуватися як частина єдиної регіональної стратегії. Фільтром ресурсів забезпечуються організаційноекономічними ресурсами всі процеси в рамках формування територіальної структури. Фільтром ризиків оцінюється територіальна структура 3 точки зору ризиків за кожним напрямком діяльності. 
Фільтром фінансів територіальна структура оцінюється з точки зору іiі спроможності.

Таким чином, організаційноекономічне забезпечення розвитку територіальної структури регіонального господарювання доцільно розглядати як сукупність економічних відносин, принципів, методів, інструментів і форм організації господарської діяльності в регіоні 3 метою забезпечення сталого розвитку шляхом гармонізації інтересів всіх зацікавлених сторін.

\section{Обговорення результатів}

На основі аналізу узагальнення теоретичних досліджень розвитку територіальної структури регіонального господарювання розроблено концепцію іiі організаційно-економічного забезпечення, що складається 3 комплексного аналізу організаційно-економічних i фінансових передумов формування територіальної структури; формування i розвитку територіальної структури регіонального господарювання шляхом організаційноекономічного i фінансового забезпечення; забезпечення регіонального стратегічного розвитку територіальної структури.

Застосування запропонованої концепції організаційно-економічного забезпечення територіальної структури регіонального господарювання дозволить приймати обгрунтовані рішення щодо іï подальшого розвитку.

Таким чином, при формуванні концепції організаційно-економічного забезпечення розвитку територіальної структури регіонального господарювання має сенс виходити 3 розуміння: по перше, комплексності впливу всіх елементів організаційно-економічного забезпечення, по-друге, необхідності сбалансованого розвитку, по-третє, поліструктурності і багаторівневості його розгляду. Це дозволить формалізувати концепцію організаційно-економічного забезпечення розвитку територіальної структури регіонального господарювання, схема якої представлена на рис. 1 .

Практичне значення запропонованої концепції полягає у створенні оптимальних передумов для формування i розвитку територіальної структури регіонального господарювання та гармонізації інтересів усіх зацікавлених сторін.

\section{Висновок}

Формування організаційноекономічного забезпечення розвитку територіальної структури регіонального господарювання неможливо відділити від форми об'єднання інтересів у господарській сфері, тобто від організаційної форми господарювання. Беручи до уваги, що в роботах сучасних вчених відзначається важлива роль цільового формування керованих замкнутих вертикальноінтегрованих виробничих циклів в підвищенні ефективності функціонування суб'єктів господарювання конкретної території, представляється доцільним розгляд можливості застосування інтеграційних об'єднань у формуванні та розвитку територіальної структури регіонального господарювання і вважаємо їх розгляд метою подальших досліджень.

\section{Список літератури}

1. Жубаркин С.В. Формирование организационно-экономического механизма развития сельских территорий. Збірник наукових праџь Таврійського державного агротехнологічного університету (економічні науки). 2013. №2(6). С. 129-139.

2. Школинський С.В. Организационноэкономическое обеспечение инновационного развития региона. Вестник Московского университета имени С.Ю. Витте. Серия 1. Экономика и управление. 2013. №2. С. 126131.

3. Кузнецов Д.В. Особенности организационно-экономического механизма региональной инновационной деятельности. Transport business in Russia. 2009. C. 160-163.

4. Маергойз И.М. Методика мелкомасштабных экономико-географических исследований. Москва: Изд-во МГУ, 1981. $137 \mathrm{c}$.

5. Лепа Р.М., Руссіян О.А. Організаційне забезпечення формування програми економічного і соціального розвитку міста. Научный вестник ДГМА. 2014. №1(13Е). C. $152-158$.

6. Токарев А.А. Организационноэкономический механизм развития региона. Современная экономика: проблемы и решения. 2016. №11(83). C. 178-191.

7. Гребенкина С.А. Механизм управления экономическим развитием региона. Гуманитарный научный журнал. 2015. №2. C. 13-14. 
8. Герасенко В.П. Развитие структуры механизма управления регіоном. Економічний вісник університету. 2015. №27/1. С. 37-44.

\section{References}

1. Zhubarkyn S.V. (2013), "Formation of the organizational and economic mechanism of development of rural territories" ["Formyrovanye orhanyzatsyonnoékonomycheskoho mekhanyzma razvytyya sel'skykh terrytoryy"], Collection of scientific works of the Tavriya State Agrotechnological University (economic sciences) [Zbirnyk naukovykh prats' Tavriys'koho derzhavnoho ahrotekhnolohichnoho universytetu (ekonomichni nauky)], №2(6), pp. 129-139.

$$
\text { 2. Shkolins'kiy S.V. (2013), }
$$

"Organizational and economic support for the innovative development of the region" ["Organizatsionno-ekonomicheskoye obespecheniye innovatsionnogo razvitiya regiona"], Bulletin of Moscow University named after S.Yu. Witte [Vestnik Moskovskogo universiteta imeni S.YU. Vitte], Seriya 1. Ekonomika i upravleniye, №2, pp. 126-131.

3. Kuznetsov D.V. (2009), "Features of the organizational and economic mechanism of regional innovation" ["Osobennosti organizatsionno-ekonomicheskogo

mekhanizma regional'noy innovatsionnoy deyatel'nosti"], Transport business in Russia, pp. 160-163.

4. Mayergoyz I.M. (1981), Methodology of small-scale economic and geographical research [Metodika melkomasshtabnykh ekonomiko-geograficheskikh issledovaniy], Moskva: Izd-vo MGU, 137 p.

5. Lepa R.M., Russiyan O.A. (2014), "Organizational support for the formation of the program of economic and social development of the city" ["Orhanizatsiyne zabezpechennya formuvannya prohramy ekonomichnoho i sotsial'noho rozvytku mista"], Scientific Bulletin of the DSEA [Nauchnyy vestnyk DHMA], №1(13E), pp. 152-158.

6. Tokarev A.A. (2016), "Organizational and economic mechanism for the development of the region" ["Organizatsionnoekonomicheskiy mekhanizm razvitiya regiona"], Modern economics: problems and solutions [Sovremennaya ekonomika: problemy i resheniya], №11(83), pp. 178-191.

7. Grebenkina S.A. (2015), "The mechanism for managing the economic development of the region" ["Mekhanizm upravleniya ekonomicheskim razvitiyem regiona"], Humanitarian Scientific Journal [Gumanitarnyy nauchnyy zhurnal], №2, pp. 1314.

8. Gerasenko V.P. (2015), "The development of the structure of the regional management mechanism" ["Razvitiye struktury mekhanizma upravleniya regíonom"], Economical newsletter to university [Yekonomíchniy vísnik uníversitetu], №27/1, pp. 37-44.

\section{ОРГАНІЗАЦІЙНО-ЕКОНОМІЧНЕ ЗАБЕЗПЕЧЕННЯ РОЗВИТКУ ТЕРИТОРІАЛЬНОЇ СТРУКТУРИ РЕГІОНАЛЬНОГО ГОСПОДАРЮВАННЯ}

Виявлено проблеми формування та розвитку територіальної структури регіонального господарювання. Узагальнено існуючі теоретичні дослідження щодо особливостей формування та розвитку територіальної структури регіонального господарювання. Обгрунтовано доцільність формування організаційно-економічного забезпечення розвитку територіальної структури регіонального господарювання. Відзначено, що для вирішення завдань координації та взаємодії всіх зацікавлених сторін у формуванні та розвитку територіальних структур господарства, для запобігання «розпилення сил» і дублювання функцій доцільно охарактеризувати складові іiі організаційно-економічного забезпечення.

Розроблено концепцію організаційно-економічного забезпечення розвитку територіальної структури регіонального господарювання.

Мета статті. Дослідження основних складових організаційно-економічного забезпечення розвитку територіальної структури регіонального господарювання.

Результати. На основі аналізу узагальнення теоретичних досліджень розвитку територіальної структури регіонального господарювання розроблено концепцію іiі організаційно-економічного забезпечення, що складається з комплексного аналізу організаційно-економічних і фінансових передумов формування територіальної структури; формування і розвитку територіальної структури регіонального господарювання шляхом організаційно-економічного i фінансового забезпечення; забезпечення регіонального стратегічного розвитку територіальної структури. 
Висновок. Застосування запропонованої концепції організаційно-економічного забезпечення територіальної структури регіонального господарювання дозволить приймати обгрунтовані рішення щодо іiі подальшого розвитку. Практичне значення запропонованої концепції полягає у створенні оптимальних передумов для формування i розвитку територіальної структури регіонального господарювання та гармонізації інтересів усіх зацікавлених сторін.

Ключові слова: територіальна структура, регіональне господарювання, розвиток, формування, організаційно-економічне забезпечення.

Попова Ольга Юріївна - доктор економічних наук, професор, завідувач кафедри управління i фінансово-економічної безпеки ДВНЗ «Донецький національний технічний університет», м. Покровськ.

ORCID ID: 0000-0002-9093-5912

e-mail: olha.popova@donntu.edu.ua

Василишина Любов Миколаївна - старший викладач, ДВНЗ «Донецький національний технічний університет», кафедра управління і фінансово-економічної безпеки, м. Покровськ.

ORCID ID: 0000-0001-8025-7786

e-mail: liubov.vasylyshyna@donntu.edu.ua

\section{ORGANIZATIONAL AND ECONOMIC SUPPORT OF DEVELOPMENT OF TERRITORIAL STRUCTURE OF REGIONAL ECONOMY}

Problems of formation and development of territorial structure of regional economy are revealed. The existing theoretical researches concerning features of formation and development of territorial structure of regional economy are generalized. The expediency of forming organizational and economic support for the development of the territorial structure of regional management is substantiated. It is noted that to solve the problems of coordination and interaction of all stakeholders in the formation and development of territorial structures of the economy, to prevent "dispersion of forces" and duplication of functions, it is advisable to characterize the components of its organizational and economic support.

The concept of organizational and economic support for the development of the territorial structure of regional management has been developed.

The purpose of the article. Research of the main components of organizational and economic support for the development of the territorial structure of regional management.

Results. On the basis of the analysis of generalization of theoretical researches of development of territorial structure of regional economy the concept of its organizational and economic maintenance consisting of the complex analysis of organizational and economic and financial preconditions of formation of territorial structure is developed; formation and development of the territorial structure of regional management through organizational, economic and financial support; ensuring the regional strategic development of the territorial structure.

Conclusion. The application of the proposed concept of organizational and economic support of the territorial structure of regional management will allow to make informed decisions about its further development. The practical significance of the proposed concept is to create optimal conditions for the formation and development of the territorial structure of regional management and harmonization of the interests of all stakeholders.

Keywords: territorial structure, regional management, development, formation, organizational and economic support.

Popova Olha - D.Sc. (Economics), Professor, Head of the Department of Management and Financial and Economic Security, Donetsk National Technical University, Pokrovsk, Ukraine

ORCID ID: 0000-0002-9093-5912

e-mail: olha.popova@donntu.edu.ua

Vasylyshyna Liubov - Senior lecturer, Donetsk national technical university, Department of Management and Financial and Economic Security, Pokrovsk

ORCID ID: 0000-0001-8025-7786

e-mail: liubov.vasylyshyna@donntu.edu.ua

\section{ОРГАНИЗАЦИОННО-ЭКОНОМИЧЕСКОЕ ОБЕСПЕЧЕНИЕ РАЗВИТИЯ ТЕРРИТОРИАЛЬНОЙ СТРУКТУРЫ РЕГИОНАЛЬНОГО ХОЗЯЙСТВА}


Выявлены проблемы формирования и развития территориальной структуры регионального хозяйства. Обобщены существующие теоретические исследования об особенностях формирования и развития территориальной структуры регионального хозяйства. Обоснована целесообразность формирования организационно-экономического обеспечения развития территориальной структуры регионального хозяйства. Отмечено, что для решения задач координации и взаимодействия всех заинтересованных сторон в формировании и развитии территориальных структур хозяйства, для предотвращения «распыления сил» и дублирования функций целесообразно охарактеризовать составляющие ее организационно-экономического обеспечения.

Разработана концепция организационно-экономического обеспечения развития территориальной структуры регионального хозяйства.

Цель статьи. Исследование основных составляющих организационно-экономического обеспечения развития территориальной структуры регионального хозяйства.

Результаты. На основе анализа обобщения теоретических исследований развития территориальной структуры регионального хозяйства разработана концепция ее организационноэкономического обеспечения, которая включает комплексный анализ организационно-экономических и финансовых предпосылок формирования территориальной структуры; формирование и развитие территориальной структуры регионального хозяйствования путем организационно-экономического и финансового обеспечения; обеспечение регионального стратегического развития территориальной структуры.

Выводы. Применение предложенной концепции организационно-экономического обеспечения территориальной структуры регионального хозяйствования позволит принимать обоснованные решения по ее дальнейшему развитию. Практическое значение предложенной концепции заключается в создании оптимальных условий для формирования и развития территориальной структуры регионального хозяйства и гармонизации интересов всех заинтересованных сторон.

Ключевые слова: территориальная структура, региональное хозяйствования, развитие, формирование, организационно-экономическое обеспечение.

Попова О.Ю. - доктор экономических наук, профессор, заведующая кафедрой управления и финансово-экономической безопасности, Донецкий национальный технический университет, г. Покровск

ORCID ID: 0000-0002-9093-5912

e-mail: olha.popova@donntu.edu.ua

Василишина Л.Н. - старший преподаватель, Донецкий национальный технический университет, кафедра управления и финансово-экономической безопасности, г. Покровск

ORCID ID: 0000-0001-8025-7786

e-mail: liubov.vasylyshyna@donntu.edu.ua 